\title{
Elucidating the Nature of Fe species during Pyrolysis of the Fe-BTC MOF into Highly Active and Stable Fischer-Tropsch Catalysts
}

Tim A. Wezendonk ${ }^{1}$, Vera P. Santos ${ }^{2}$, Maxim A. Nasalevich ${ }^{1}$, Quirinus S.E. Warringa ${ }^{1}$, A. Iulian Dugulan $^{4}$, Adam Chojecki ${ }^{2}$, Ard Koeken ${ }^{3}$, Matthijs Ruitenbeek ${ }^{3}$, Garry Meima ${ }^{2}$, Husn-Ubayda Islam ${ }^{5}$, Gopinathan Sankar ${ }^{5}$, Michiel Makkee ${ }^{1}$, Freek Kapteijn ${ }^{1, *}$ and Jorge Gascon ${ }^{1, *}$

${ }^{1}$ Catalysis Engineering, Chemical Engineering Department, Delft University of Technology, Julianalaan 136, 2628 BL Delft, The Netherlands

${ }^{2}$ Core R\&D, ${ }^{3}$ Hydrocarbons R\&D, Dow Benelux B.V., P.O. Box 48, 4530 AA, Terneuzen, The Netherlands

${ }^{4}$ Fundamental Aspects of Materials and Energy Group, Delft University of Technology, 2629 JB Delft, Netherlands.

${ }^{5}$ Department of Chemistry, University College London, 20 Gordon Street, WC1H 0AJ, London, UK

KEYWORDS: Fischer-Tropsch synthesis, Iron, Metal Organic Framework, MOF mediated synthesis, Pyrolysis, Structure-activity relations, Iron carbide phases, Dispersion.

\section{Corresponding Author}

* f.kapteijn@tudelft.nl,j.gascon@tudelft.nl 


\section{Experimental supplement}

\subsection{XAFS data analysis}

All the XAFS data were merged in Horae Athena and the exported file was further processed with VIPER software for normalisation and background subtraction. Subsequent detailed analysis was performed using EXCURVE software. Fe foil was used to extract the amplitude reduction factor. This value of 0.75 was fixed for the analysis of the remaining data sets. In the EXCURVE software, it is possible to include single-scattering paths of various shells without the need for a crystal structure, and refine until the best fit between experiment and theory is achieved. The model used for simulating the room temperature EXAFS spectrum of Fe-BTC was based on the crystallographic data reported by Horcajada et al. ${ }^{1}$ This method is particularly useful in very complex systems such as the one described here. The software allows estimation of the change in $R$-factor and, therefore, validates including additional shells. In addition, it is also possible to constrain two closely similar parameters to the same value. For example, in some cases the $\mathrm{Fe}-\mathrm{C}$ and $\mathrm{Fe}-\mathrm{O}$ are assumed to have similar Debye-Waller factors.

\subsection{Mössbauer analysis}

The high-pressure Mössbauer in situ cell developed at Reactor Institute Delft is manufactured of stainless steel SS316L and capable of going up to $25 \mathrm{bar}$ of gas mixtures at temperatures of $450{ }^{\circ} \mathrm{C}$ (Figure S0a). It allows for combined Mössbauer spectroscopy in transmission mode and IR spectroscopy in DRIFT configuration. At the top of the cell a CVD diamond window is mounted, allowing the IR measurements, while a beryllium window is included at the bottom, having high permeability to the gamma rays used in Mössbauer spectroscopy (Figure S0b). The sample is mounted inside the cell in holders containing graphite discs at the bottom and the cell is closed with gold plated metal C-rings. The gas flows through the catalyst bed from top to bottom, the inlet gas being preheated in the heating compartment. The cell can be mounted on transport tubes and cooled down to $4.2 \mathrm{~K}$ in a cryostat for lowtemperature Mössbauer measurements. One Mössbauer spectrum was recorded each time at room temperature for 10-15 h until a satisfactory signal-to-noise ratio was achieved. Subsequently, the cell was cooled down using liquid He and the low temperature Mössbauer spectrum was recorded. The measurements at liquid He temperature were used for data deconvolution, however both spectra provided much qualitative input on the system studied. The Mössbauer spectra were fitted using the Mosswinn 4.0 program. ${ }^{2}$ The high-pressure beryllium windows used in this cell contain $0.08 \% \mathrm{Fe}$ impurity whose spectral contribution was fitted and removed from the final spectra. Experimental uncertainties in the isomer shift $(I S) \pm 0.01 \mathrm{~mm} \mathrm{~s}^{-1}$; in the quadrupole splitting $(Q S) \pm$ $0.01 \mathrm{~mm} \mathrm{~s}^{-1}$; in the line width $(\Gamma) \pm 0.01 \mathrm{~mm} \mathrm{~s}^{-1}$; in the hyperfine field $\pm 0.1 \mathrm{~T}$; and in the spectral contribution $\pm 3 \%$

\subsection{HR-TEM calculation of dispersion}

The dispersion $D$ (equation $\mathrm{S} 1$ ) is calculated as number of surface atoms $N_{\mathrm{s}}$ divided by the total amount of atoms $N_{\mathrm{t}}$, excluding the agglomerate fraction beyond the Gauss distribution. From the particle analysis, we calculate a surface area $A$ to volume ratio $V$ by dividing the sum of the areas over the total volume of the particles counted. The surface density of Fe atoms $(n)$ was calculated with the atom count from the main plane in XRD (110) of the BCC lattice with associated lattice constant $(a=2.856 \AA)$. Avogadro's number $N_{\mathrm{A}}$, molar mass $M_{\mathrm{m}}$ and bulk density $\rho_{\mathrm{Fe}}$ were used as found in Perry's handbook. ${ }^{3}$ The dispersion, total particle count and agglomerate fraction for the Fe@C samples is given in table S1.

$$
D=\frac{N_{s}}{N_{t}}=\frac{A}{V} \frac{M_{m} n_{110}}{N_{A} \rho_{F e}} \times 100 \%
$$

Table S0: Particle counts on HR-TEM analysis of Fe@C

\begin{tabular}{|l|l|l|l|}
\hline Catalyst & $D / \%$ & Particle counts / - & Agglomerate fraction / \% \\
\hline $\mathrm{Fe} @ \mathrm{C}-400$ & 50 & 251 & 1.6 \\
\hline $\mathrm{Fe} @ \mathrm{C}-500$ & 32 & 680 & 5.1 \\
\hline $\mathrm{Fe} @ \mathrm{C}-600$ & 19 & 263 & 4.5 \\
\hline $\mathrm{Fe} @ \mathrm{C}-900$ & 4 & 523 & 6.6 \\
\hline
\end{tabular}



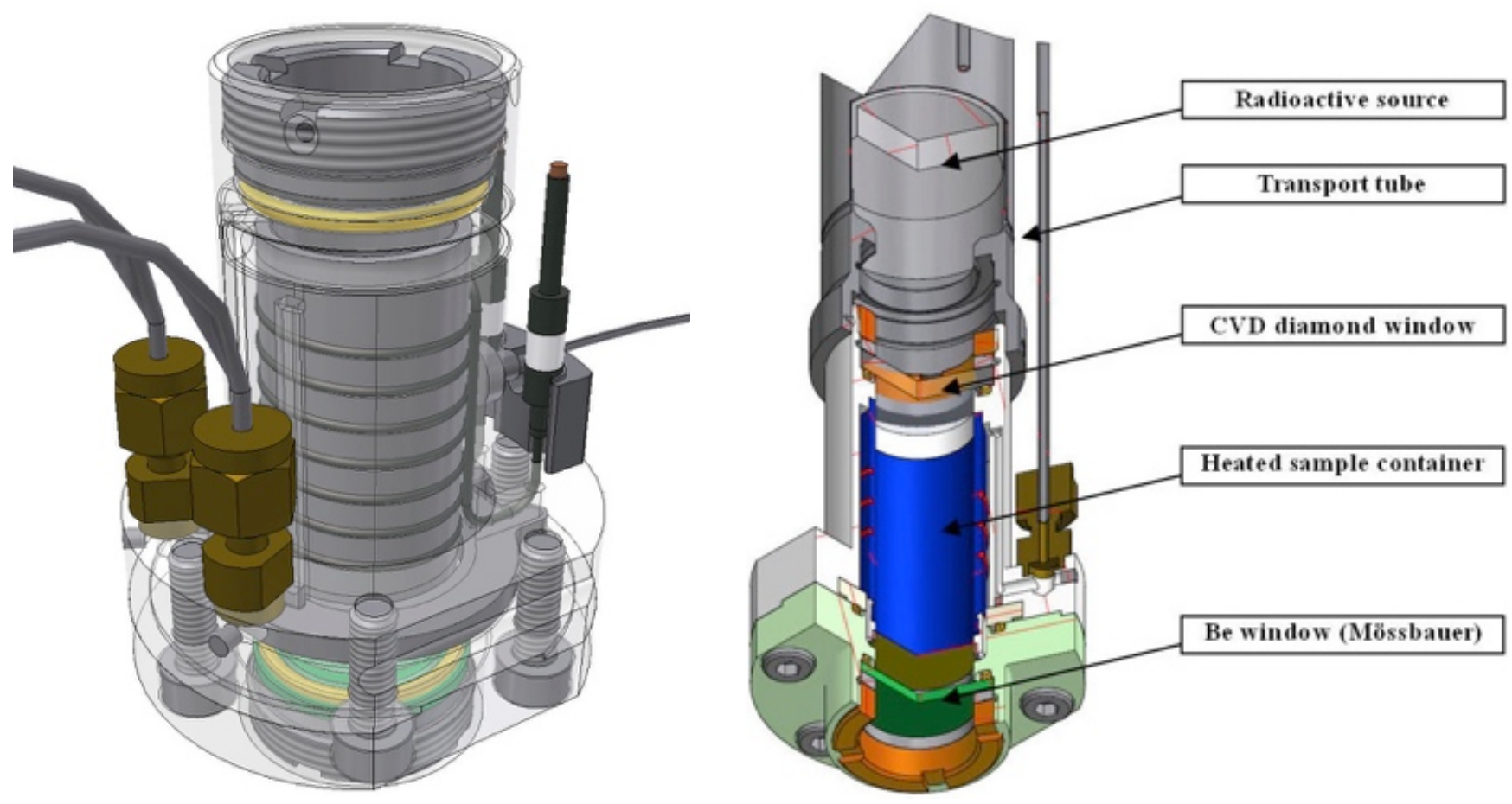

Figure S0. Mössbauer high-pressure in situ cell exterior (left) and interior (right).

\subsection{Catalytic performance ${ }^{4}$}

$\mathrm{CO}$ conversion and carbon selectivity were defined by equations S2 and S3, respectively, where $X_{C O}$ stands for CO conversion, $F$ indicates the molar flow, $S$ is the carbon selectivity towards a product with $n$ carbon atoms and $y$ is the molar fraction of a hydrocarbon $\mathrm{C} n$. Catalytic activity is expressed as iron time yield (FTY), defined as the number of CO moles converted to hydrocarbons per gram of iron per second. The carbon balance was satisfied by $95 \pm 1 \%$ for all experiments. The apparent turnover frequency $(T O F)$ was calculated for the catalysts pyrolyzed between $400-600{ }^{\circ} \mathrm{C}$ and was obtained from equation $\mathrm{S} 4$. Fe@C-900 was not considered in the TOF analysis because of the wide particle size distribution of the polydisperse particles and absent Mössbauer data for this catalyst. Gas hourly space velocity $\left(G H S V=30,000 \mathrm{~h}^{-1}\right)$ is defined as the ratio of the volumetric flow rate (STP) over the catalyst bed volume.

$$
X_{C O}=\left(1-\frac{C_{H e, d, R} \cdot C_{C O, d, R}}{C_{H e, d, b l k} \cdot C_{C O, d, b l k}}\right) \cdot 100 \%
$$

where $C_{H e, d, b l k}, C_{H e, d, R}, C_{C O, d, b l k}, C_{C O, d, R}$ are the concentrations determined by GC analysis of He in the blank, He in the diluted reactor effluent, $\mathrm{CO}$ in the blank, and $\mathrm{CO}$ in the diluted reactor effluent, respectively.

$$
S_{C n}=\frac{n \cdot\left(\frac{C_{C n, d, R}}{C_{H e, d, R}}\right)}{\left(\frac{C_{C O, d, b l k}}{C_{H e, d, b l k}}-\frac{C_{C O, d, R}}{C_{H e, d, R}}\right)} \cdot 100 \%
$$

where $C_{C n, d, R}$ is the concentration the diluted reactor effluent determined be GC analysis of a product with $\mathrm{n}$ carbon atoms.

$$
T O F=\frac{X_{C O} F_{C O}^{i n}\left(1-S_{\mathrm{CO}_{2}}\right)}{\frac{w_{\mathrm{Fe}}}{M_{m}} D \varepsilon}
$$

where $X_{C O}$ is the carbon conversion, $F_{C O \text {, in }}$ the molar flow of $\mathrm{CO}$ in the inlet, $S_{\mathrm{CO} 2}$ the selectivity towards $\mathrm{CO}_{2}, w_{F e}$ the mass of Fe in the catalyst, $M_{m}$ the molar mass of Fe, $D$ the metal dispersion and $\varepsilon$ the amount of carbide after exposure to syngas determined by Mössbauer spectroscopy. 


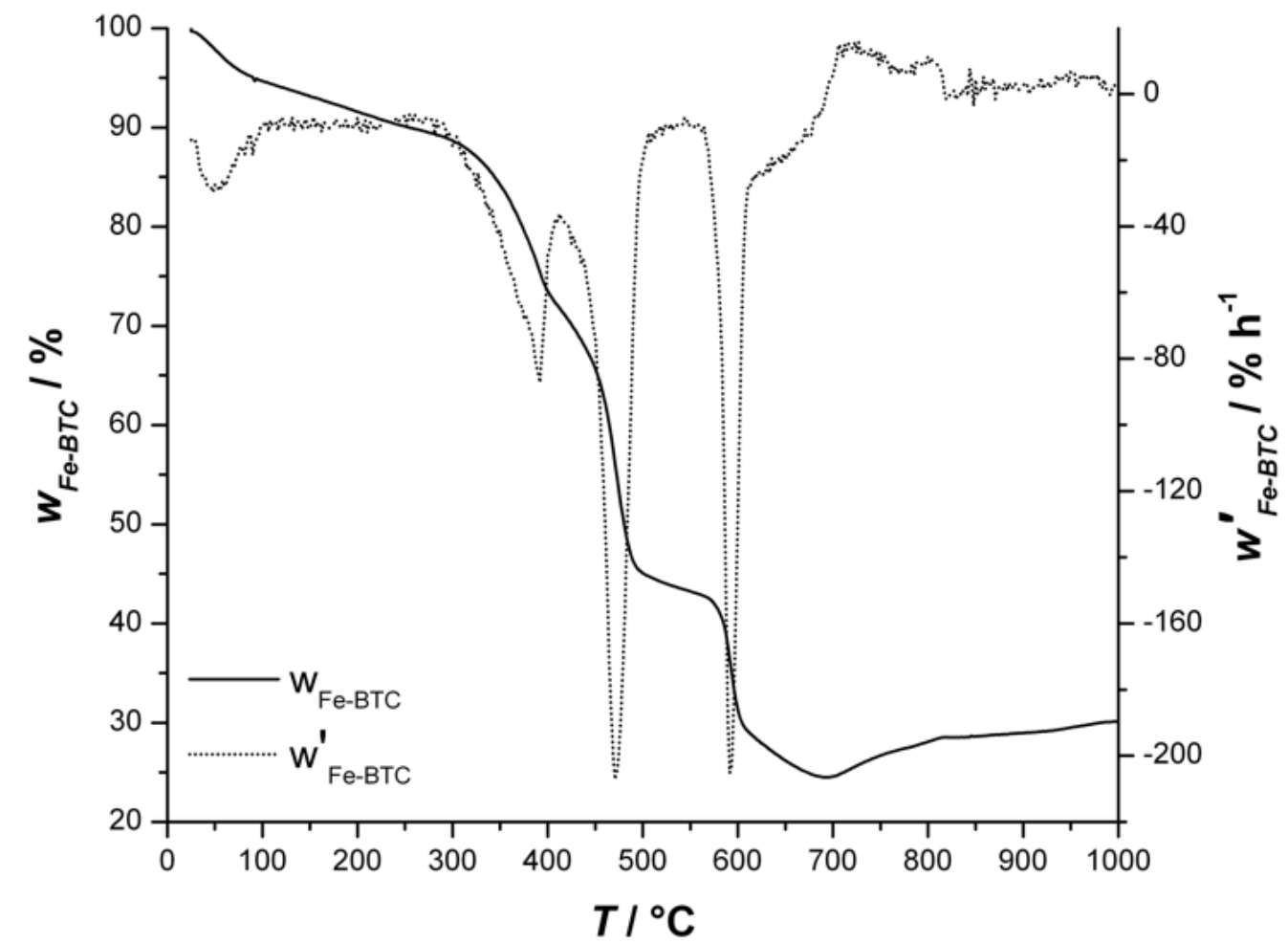

Figure S1. TGA of Fe-BTC pyrolysis under He showing the weight loss as a function of the pyrolysis temperature $(T)$ applied, indicating three regions of large mass losses.

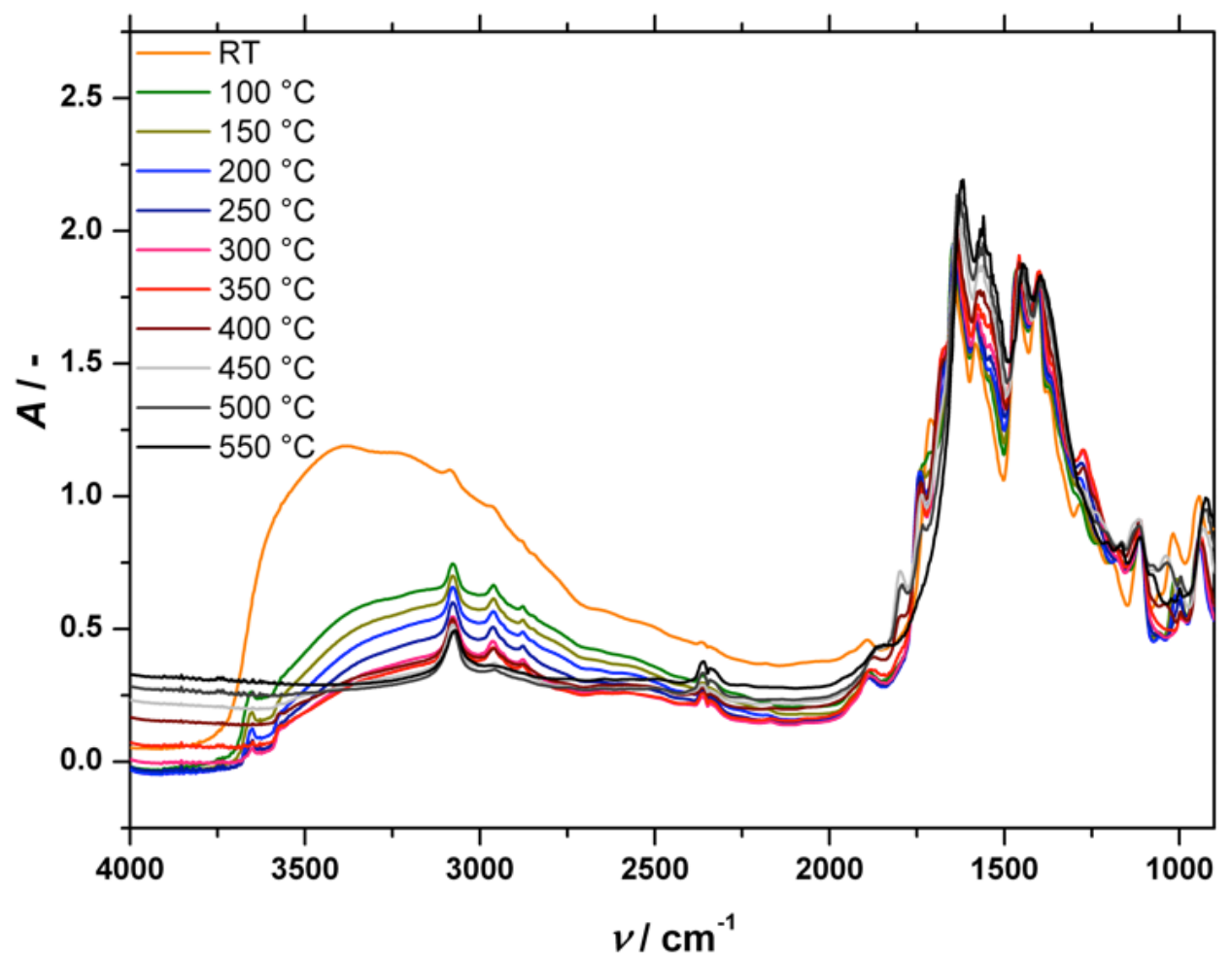

Figure S2. Full DRIFT spectra of Fe-BTC pyrolysis in He showing spectra obtained at set point temperature reached with $2{ }^{\circ} \mathrm{C} / \mathrm{min}$, showing the initial hydration of $\mathrm{Fe}-\mathrm{BTC}$, the release of free acid during pyrolysis and the formation of pyrolysis products such as $\mathrm{CO}_{2}$. 

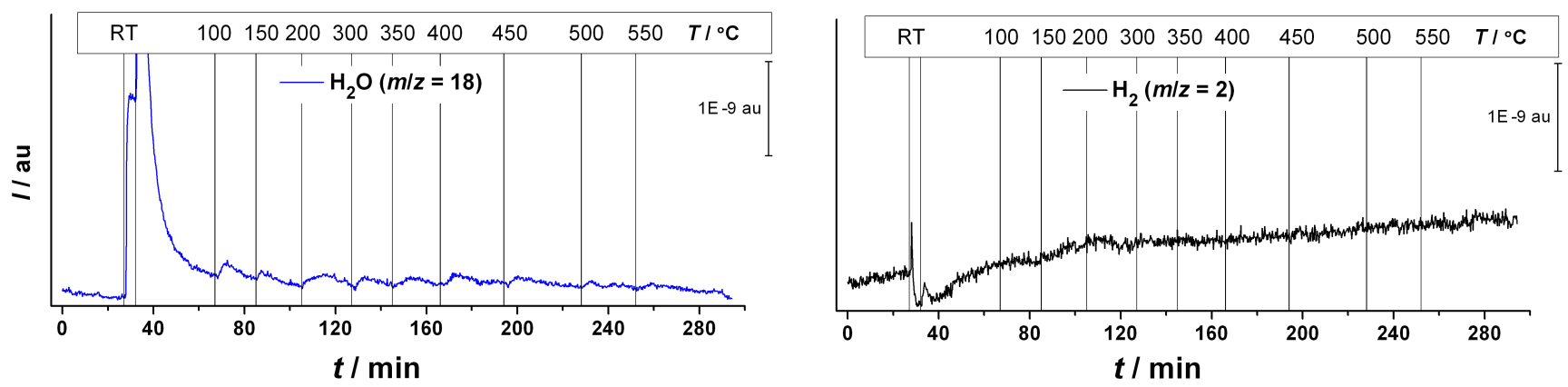

Figure S3. Mass spectra of effluent gas during Fe-BTC pyrolysis in He with indications when the temperature $(T)$ was increased to the setpoint value.

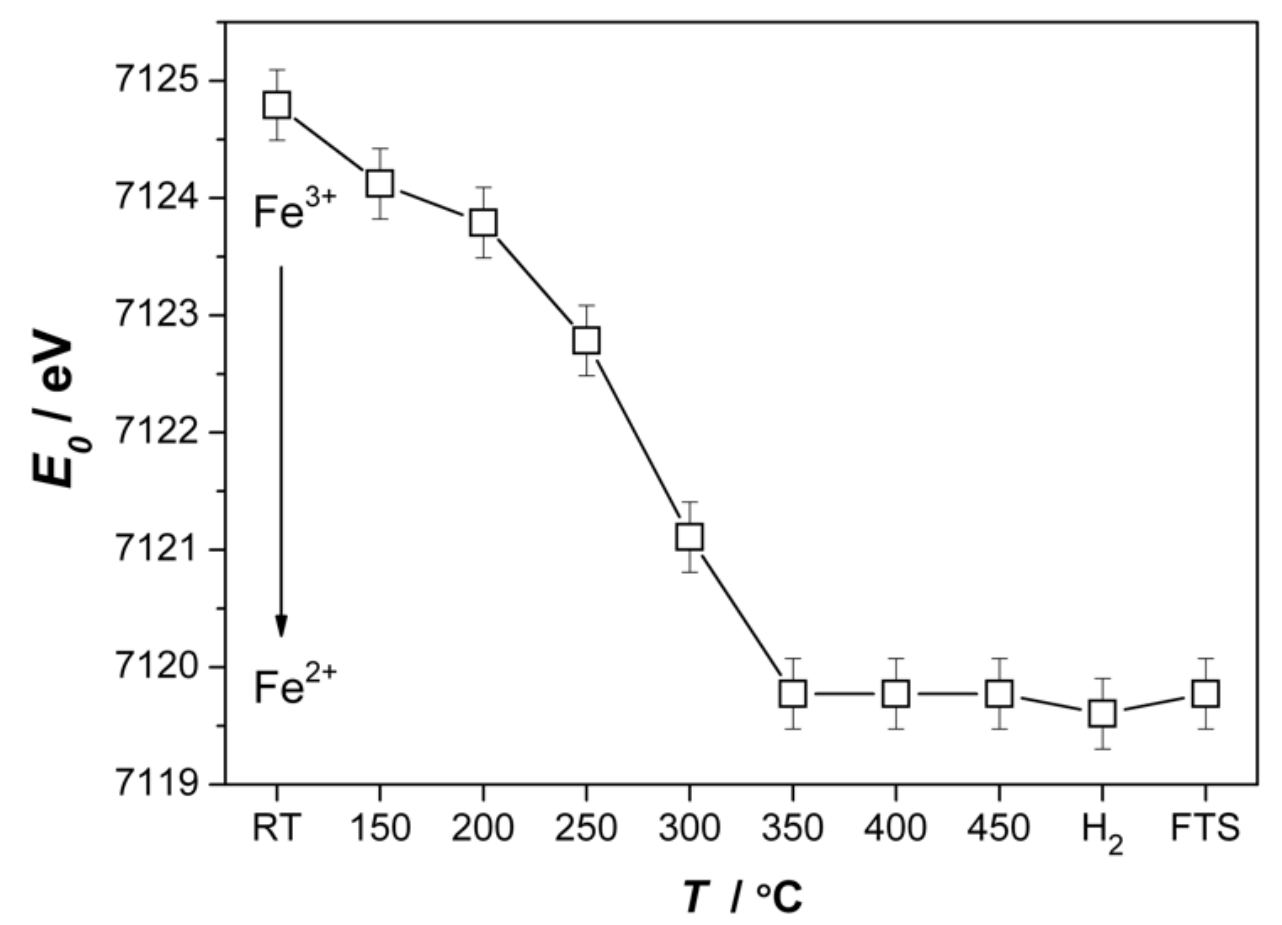

Figure S4. XANES-spectra derived edge energy positions $\left(E_{0}\right)$ indicating a decrease in Fe oxidation state during pyrolysis, while maintaining that bulk oxidation state during reduction for $3 \mathrm{~h}$ in $10 \mathrm{vol} \% \mathrm{H}_{2}$ at $400{ }^{\circ} \mathrm{C}$ and during $5 \mathrm{~h} \mathrm{HT}-\mathrm{FTS}$ at $340{ }^{\circ} \mathrm{C}$ and $2 \mathrm{bar}$ with $\mathrm{CO} / \mathrm{H}_{2}=1$. 


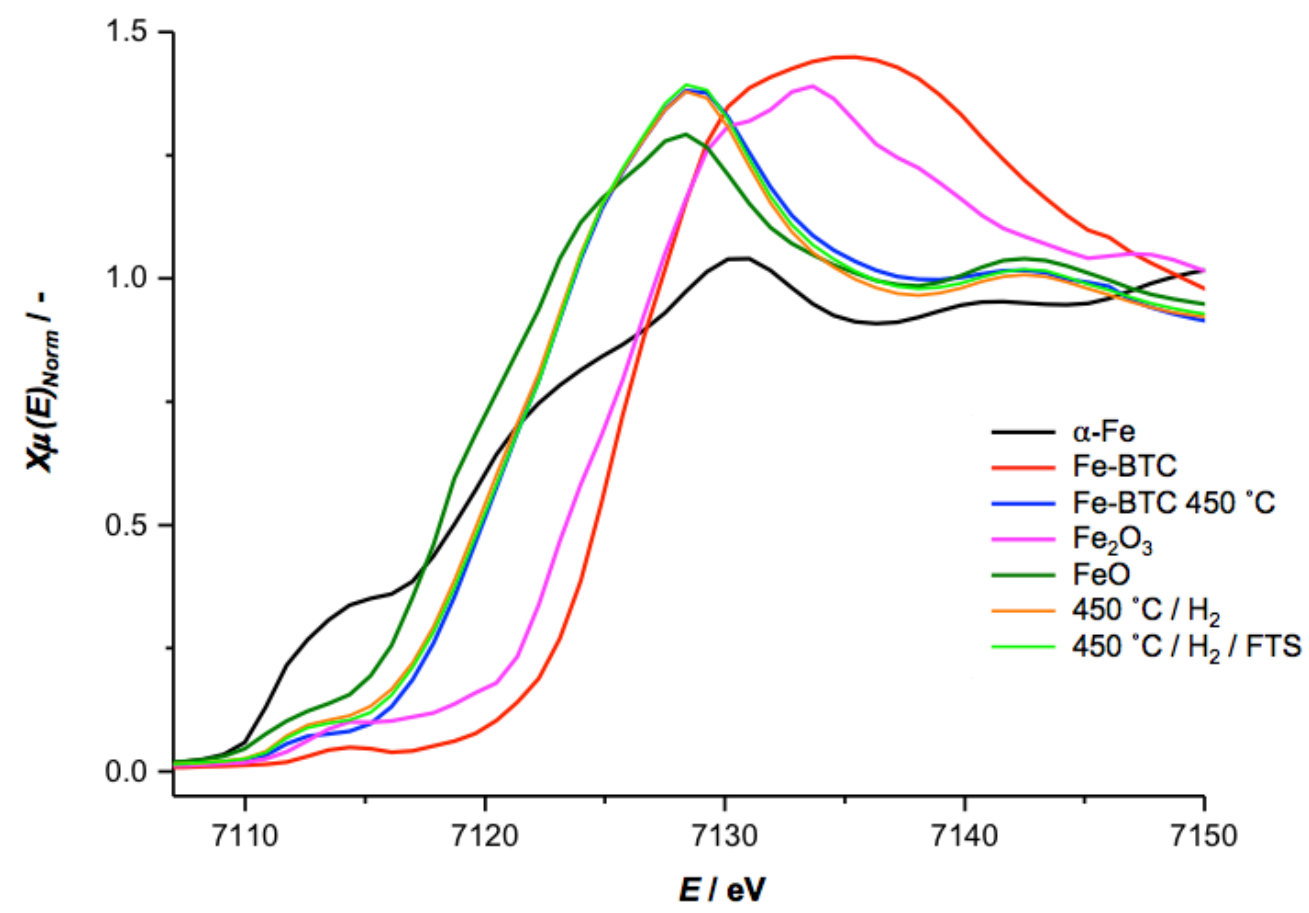

Figure S5. XAFS experimental XANES region displaying spectra of Fe-BTC, the pyrolyzed compound, subsequently reduced and under HT-FTS conditions, together with the reference materials used for correlating data.
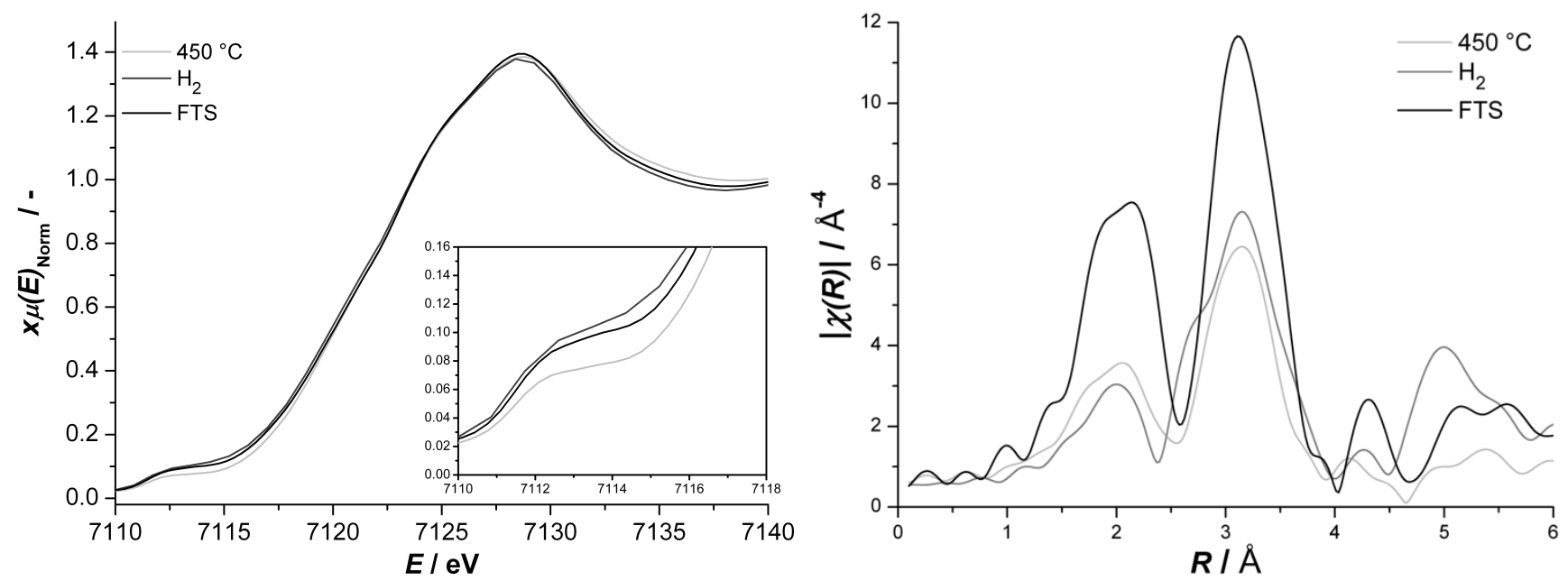

Figure S6. In situ XAFS spectra of pyrolyzed Fe-BTC subsequently reduced in $10 \mathrm{vol} \% \mathrm{H}_{2}$ at $400{ }^{\circ} \mathrm{C}$ and 1 bar for $3 \mathrm{~h}$ and under $\mathrm{HT}$-FTS at $340{ }^{\circ} \mathrm{C}$ and 2 bar after $5 \mathrm{~h}$; showing the XANES with pre-edge insert (left), and magnitude of the FT EXAFS signal of the same experiment (right). 
Table S1. EXAFS fitting results of the spectra recorded after pyrolysis in He at different temperatures and subsequent reduction in hydrogen for $3 \mathrm{~h}$ at $400{ }^{\circ} \mathrm{C}$ and 1 bar and exposure to syngas for $5 \mathrm{~h}$ at $340{ }^{\circ} \mathrm{C}$ and 2 bar using an equimolar $\mathrm{CO} / \mathrm{H}_{2}$ ratio and total flow rates of $20 \mathrm{~cm}^{3} \mathrm{STP}_{\mathrm{min}}^{-1}$.

\begin{tabular}{|c|c|c|c|c|c|}
\hline $\begin{array}{l}\text { Temperature } \\
T /{ }^{\circ} \mathrm{C}\end{array}$ & $\begin{array}{l}\text { Shell } \\
\text { Number }\end{array}$ & Scatterer & $\begin{array}{l}\text { Coordination } \\
\text { Number } \\
N / \text { - }\end{array}$ & $\begin{array}{l}\text { Distance } \\
\mathbf{R} / \AA\end{array}$ & $\begin{array}{l}\text { Debye-Waller } \\
\text { factor } \\
\Delta \sigma^{2} / \AA^{2}\end{array}$ \\
\hline \multirow[t]{3}{*}{ RT } & 1 & $\mathrm{O}$ & 6 & 1.998 & 0.014 \\
\hline & 2 & $\mathrm{C}$ & 4 & 2.958 & 0.019 \\
\hline & 3 & $\mathrm{Fe}$ & 2 & 3.328 & 0.016 \\
\hline \multirow[t]{3}{*}{150} & 1 & $\mathrm{O}$ & 6.0 & 2.0 & 0.021 \\
\hline & 2 & $\mathrm{C}$ & 3.6 & 2.967 & 0.026 \\
\hline & 3 & $\mathrm{Fe}$ & 2.3 & 3.328 & 0.016 \\
\hline \multirow[t]{3}{*}{200} & 1 & $\mathrm{O}$ & 6.0 & 2.0 & 0.021 \\
\hline & 2 & $\mathrm{C}$ & 3.0 & 2.964 & 0.026 \\
\hline & 3 & $\mathrm{Fe}$ & 2.4 & 3.33 & 0.033 \\
\hline \multirow[t]{3}{*}{250} & 1 & $\mathrm{O}$ & 5.8 & 2.0 & 0.023 \\
\hline & 2 & $\mathrm{C}$ & 2.6 & 2.974 & 0.027 \\
\hline & 3 & $\mathrm{Fe}$ & 1.7 & 3.33 & 0.032 \\
\hline \multirow[t]{3}{*}{300} & 1 & $\mathrm{O}$ & 5.3 & 2.0 & 0.023 \\
\hline & 2 & $\mathrm{C}$ & 2.3 & 3.01 & 0.029 \\
\hline & 3 & $\mathrm{Fe}$ & 1.9 & 3.33 & 0.033 \\
\hline \multirow[t]{3}{*}{350} & 1 & $\mathrm{O}$ & 5.1 & 2.0007 & 0.023 \\
\hline & 2 & $\mathrm{C}$ & 2.0 & 2.97 & 0.031 \\
\hline & 3 & $\mathrm{Fe}$ & 1.1 & 3.247 & 0.033 \\
\hline \multirow[t]{3}{*}{400} & 1 & $\mathrm{O}$ & 4.5 & 2.0007 & 0.023 \\
\hline & 2 & $\mathrm{C}$ & 1.7 & 3.0 & 0.033 \\
\hline & 3 & $\mathrm{Fe}$ & 0.9 & 3.286 & 0.033 \\
\hline \multirow[t]{6}{*}{450} & 1 & $\mathrm{C}$ & 2.2 & 2.115 & 0.026 \\
\hline & 2 & $\mathrm{O}$ & 2.3 & 2.250 & 0.026 \\
\hline & 3 & $\mathrm{Fe}$ & 0.5 & 2.503 & 0.033 \\
\hline & 4 & $\mathrm{Fe}$ & 4.0 & 3.055 & 0.033 \\
\hline & 5 & $\mathrm{Fe}$ & 5.6 & 3.219 & 0.033 \\
\hline & 6 & $\mathrm{Fe}$ & 2.4 & 3.407 & 0.034 \\
\hline \multirow[t]{6}{*}{$400 / \mathrm{H}_{2}$} & 1 & $\mathrm{C}$ & 2.0 & 2.158 & 0.026 \\
\hline & 2 & $\mathrm{O}$ & 2.1 & 2.287 & 0.026 \\
\hline & 3 & $\mathrm{Fe}$ & 1.2 & 2.525 & 0.033 \\
\hline & 4 & $\mathrm{Fe}$ & 3.0 & 3.045 & 0.033 \\
\hline & 5 & $\mathrm{Fe}$ & 4.7 & 3.191 & 0.033 \\
\hline & 6 & $\mathrm{Fe}$ & 1.7 & 3.357 & 0.034 \\
\hline \multirow[t]{6}{*}{340 / FTS } & 1 & $\mathrm{C}$ & 2.7 & 2.099 & 0.022 \\
\hline & 2 & $\mathrm{O}$ & 2.5 & 2.194 & 0.023 \\
\hline & 3 & $\mathrm{Fe}$ & 0.8 & 2.542 & 0.033 \\
\hline & 4 & $\mathrm{Fe}$ & 8.8 & 3.089 & 0.033 \\
\hline & 5 & $\mathrm{Fe}$ & 6.7 & 3.279 & 0.033 \\
\hline & 6 & $\mathrm{Fe}$ & 2.9 & 3.510 & 0.034 \\
\hline
\end{tabular}

Amplitude reduction factor $S_{0}{ }^{2}=0.75$ was calculated from Fe foil standard was the same in all cases. Errors in $N \pm 10 \%$ and in $R \pm 0.02 \AA$. 


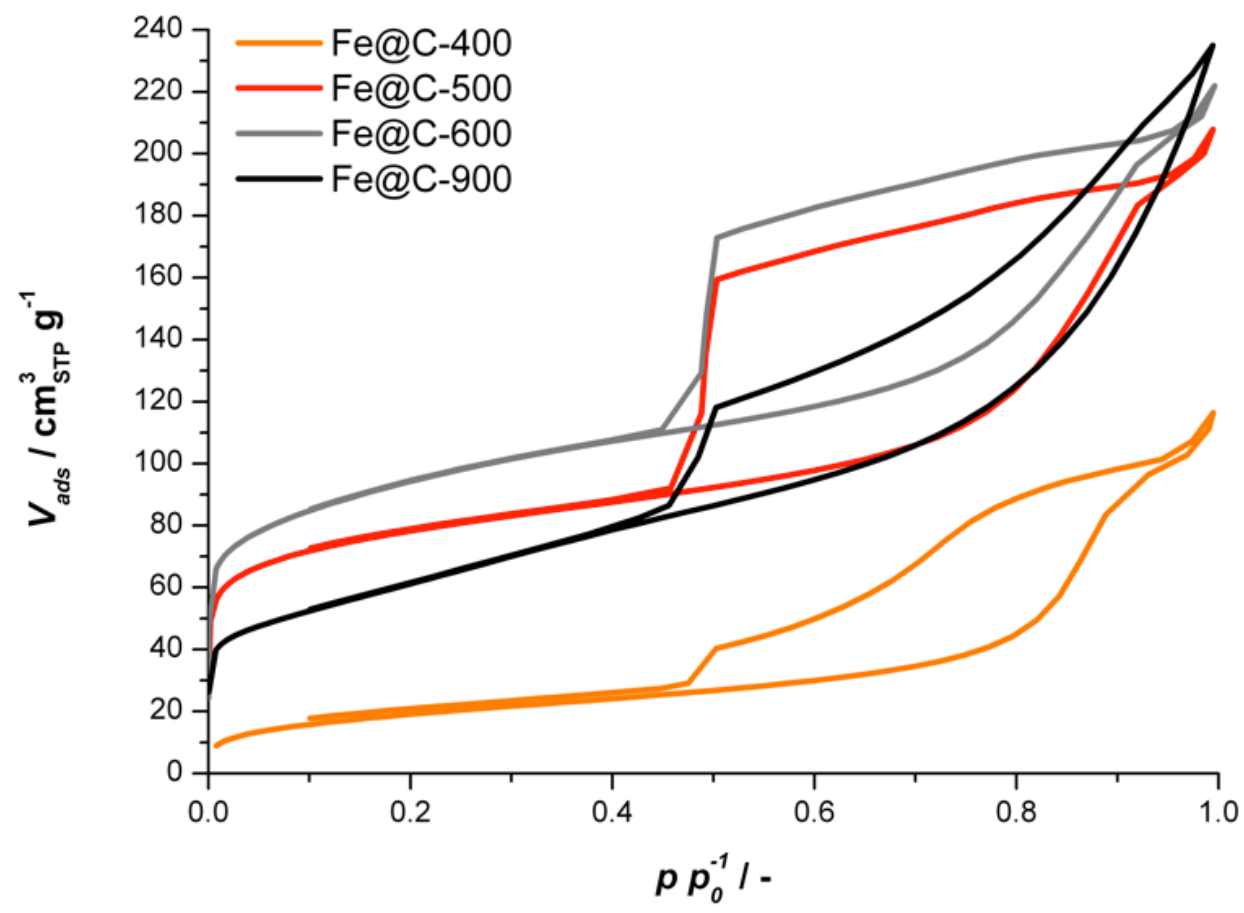

Figure S7. $\mathrm{N}_{2}$ physisorption at $77 \mathrm{~K}$ of $\mathrm{Fe} @ \mathrm{C}$ catalysts degassed at $175{ }^{\circ} \mathrm{C}$ for $16 \mathrm{~h}$ displaying the formation of mesoporous carbon with varying porosity upon pyrolysis of the microporous Fe-BTC.
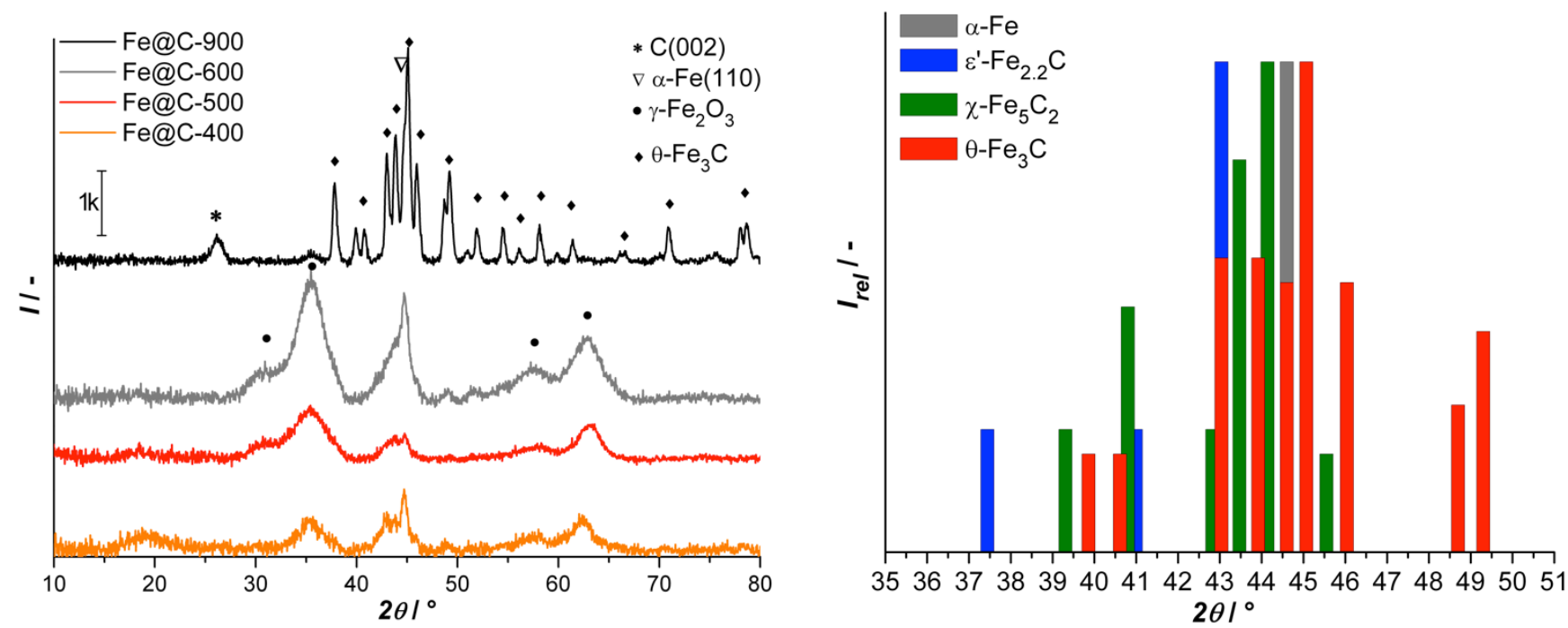

Figure S8. XRD of $\mathrm{Fe} @ \mathrm{C}$ catalysts after 2 h passivation in 5 vol $\% \mathrm{O}_{2}$ and prior to loading into FTS reactors showing the contributions of multiple Fe phases (left), and linear combination of theoretical diffraction intensities in the congested Fe-carbide region between $35-50^{\circ}$ (right). 

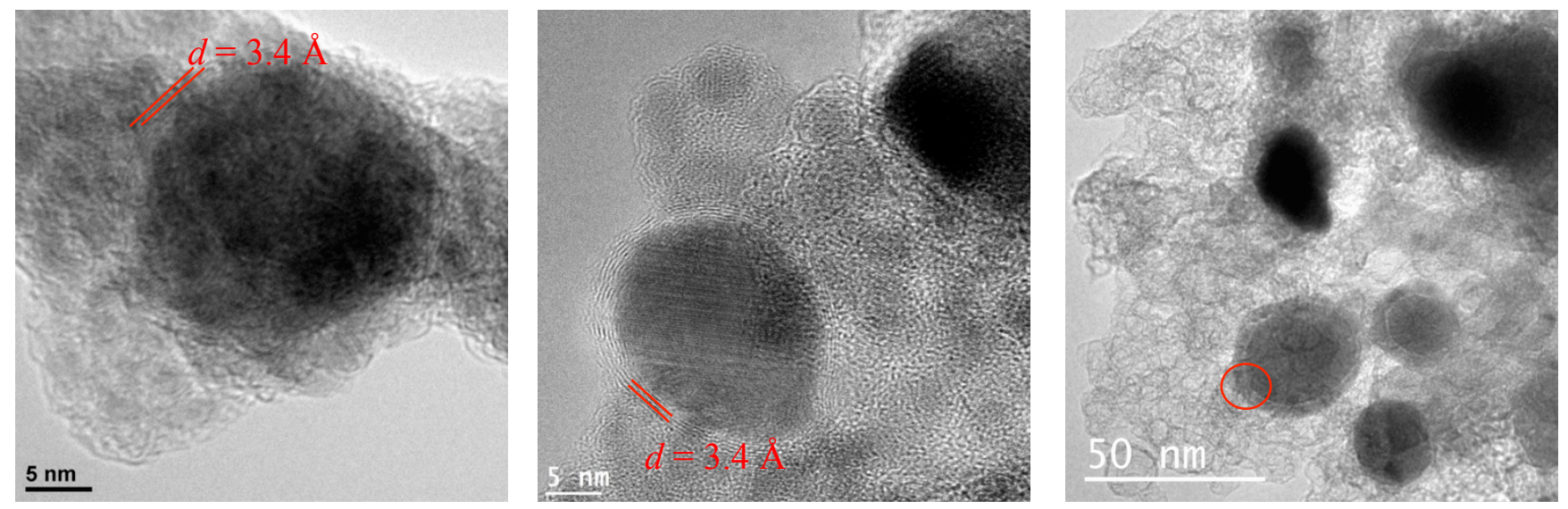

Figure S9. TEM images of agglomerates on (from left to right) Fe@C-400, Fe@C-500, and Fe@C-900 showing a graphitic shell (d=3.4 $\AA$ ) encapsulating the Fe nanoparticles, with a coarsening layer upon temperature increase.

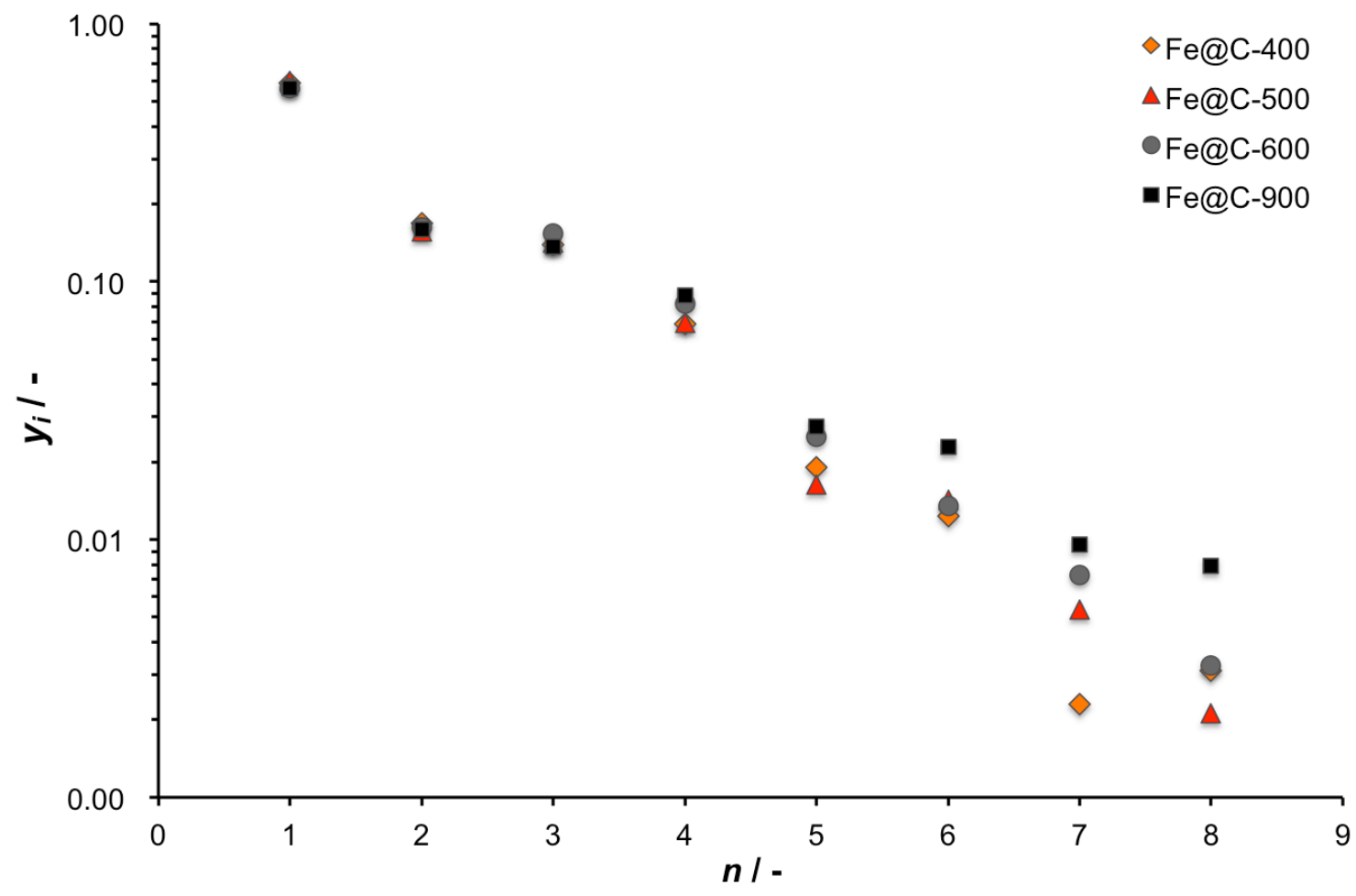

Figure S10. ASF plots for Fe@C-400, 500, 600, and 900 at $80 \mathrm{~h}$ TOS under HT-FTS conditions $\left(T=340{ }^{\circ} \mathrm{C}, P=20 \mathrm{bar}, \mathrm{CO} / \mathrm{H}_{2}=1, G H S V\right.$ $\left.=30,000 \mathrm{~h}^{-1}\right)$. The chain growth probability $\alpha(0.43-0.55)$ was calculated for the range $\mathrm{C}_{3}-\mathrm{C}_{8}$, indicative for low- $\alpha$ HT-FTS conditions. 


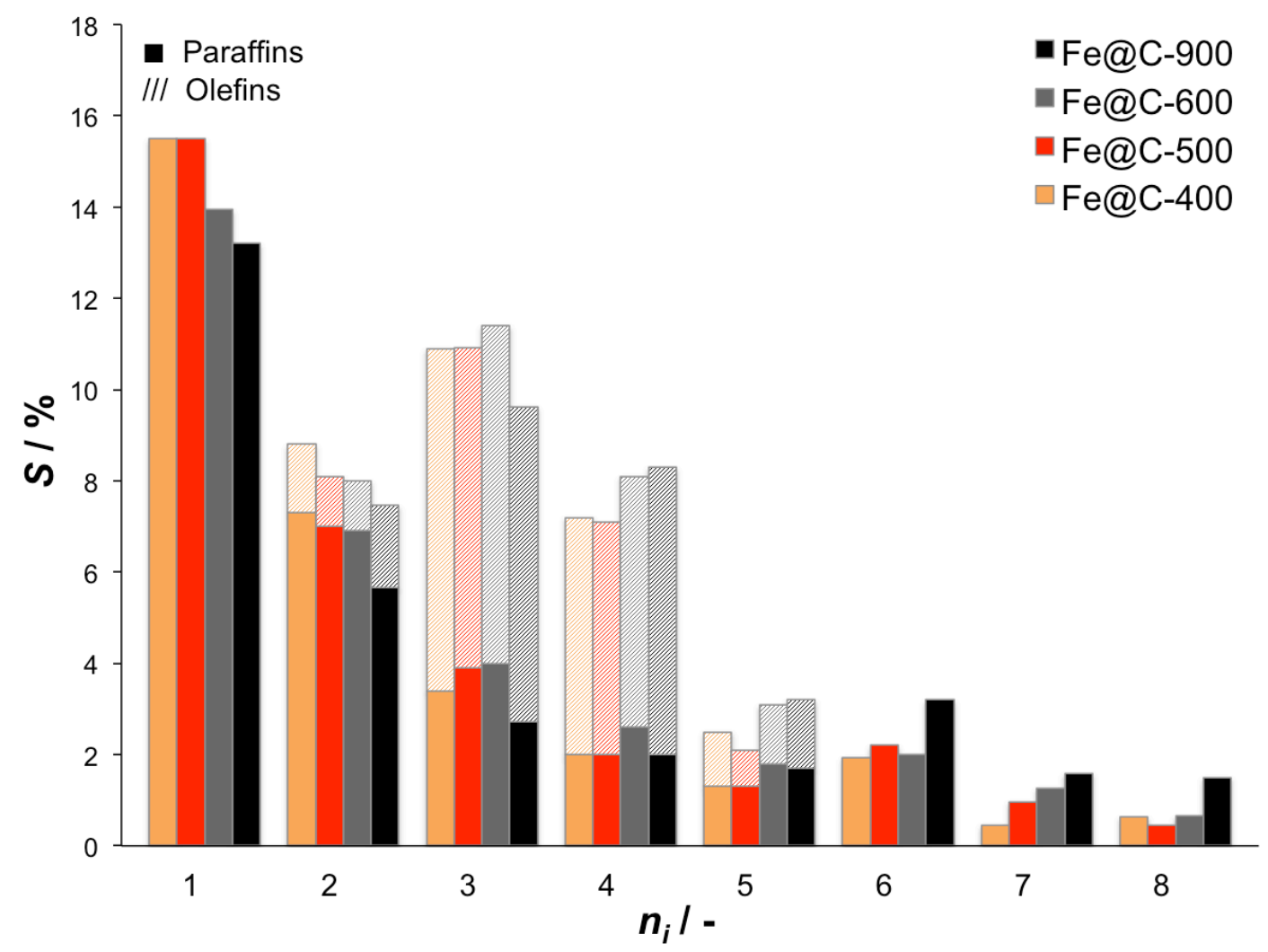

Figure S11. Product selectivity ( $S \%$, carbon based) for Fe $@$ C-400, 500, 600 and 900 at $80 \mathrm{~h}$ TOS under HT-FTS conditions $\left(T=340{ }^{\circ} \mathrm{C}, P\right.$ $=20 \mathrm{bar}, \mathrm{CO} / \mathrm{H}_{2}=1, G H S V=30,000 \mathrm{~h}^{-1}$ ) showing paraffins (solid) and olefins (hatched). Olefins and paraffins are not distinguished from $\mathrm{C}_{6}$ onwards.

\section{REFERENCES}

(1) Horcajada, P.; Surble, S.; Serre, C.; Hong, D.-Y.; Seo, Y.-K.; Chang, J.-S.; Greneche, J.-M.; Margiolaki, I.; Ferey, G. Chemical Communications 2007, 2820.

(2) Klencsár, Z. Nuclear Instruments and Methods in Physics Research Section B: Beam Interactions with Materials and Atoms 1997, $129,527$.

(3) Green, D. W.; Perry, R. H. Perry's Chemical Engineers' Handbook, Eighth Edition; McGraw-Hill Professional, 2007.

(4) (a) A. Chojecki, G. B., G. Meima, M. Bashir, C. Khare, M. Ruitenbeek "High Throughput Campaign Fischer-Tropsch to Olefin. Part 1: Validation of the Experimental Setup. Catalytic Test Results over Fused Iron Catalysts ", 2011(b) R. Edam, M. B., V. Mertens, C. Ribes, S. Beyer, E. Schmidt, A. Chojecki "Development of On-Line GC Method for High Throughput Fischer-Tropsch to Olefins Campaign-2010," 2010. 